\title{
Classification and Determination of Indicator Environmental Properties in Western Iran Rangelands
}

\author{
Reza Hasanpori ${ }^{1}$, Ali Tavili ${ }^{2}$, Seied Akbar Javadi ${ }^{3}$ \\ ${ }^{1}$ Department of Agriculture and Natural Resources, Islamic Azad University, IRAN \\ ${ }^{2}$ Associate Professor, Natural Resources Faculty, University of Tehran, IRAN \\ ${ }^{3}$ Assistant Professor, Department of Agriculture and Natural Resources, Islamic Azad University, Tehran, IRAN
}

\begin{abstract}
How soil characteristics affecting plant species density was investigated through the one-way ANOVA method in typical rangelands of Iran in Zagros Mountains region. All of present species were identified, studied, tagged and named. Four plant types were identified based on two-way indicator species analysis (TWINSPAN). Survey was done at two depths of soil $(0-30$ and $\geq 30 \mathrm{~cm})$. In each plot canopy related factors were measured and to determine chemical and physical properties of soil, at primary and end points of each transect profiles were dug. For each profile eight factors at two depths were measured inclusive: soil texture, Organic matter, total nitrogen percent, absorbable phosphorus, absorbable potassium, Lime, $\mathrm{pH}$ and EC. Means of squares comparison showed that organic matter, phosphorus, potassium, EC, sand and lime were more effective on species density at two depths in such rangeland ecosystems.
\end{abstract}

Key words: Iran; plant density; rangeland; soil characteristics; Zagros.

\section{INTRODUCTION}

Rangeland could be defined as the land on which indigenous vegetation (climax or natural potential) is predominantly grass, grass-like plants, forbs, or shrubs that are grazed or have the potential to be grazed, and which is managed as a natural ecosystem for grazing livestock and wildlife habitat(Allen et al. 2011). Proper maintenance, management and utilization of rangelands vegetation, require scientific and comprehensive cognition. Lack of knowledge about vegetation and related density of these ecosystems, cause accurate planning impossible, although these factors are index of destruction, and soil and environmental changes due to time (Mirzaiee et al. 2007). Grace (1999) suggested that species density is controlled by the effects of disturbance, total community biomass, colonization, the species pool and spatial heterogeneity (Grace 1999). The distribution of plants was largely affected by a moisture gradient that was controlled by elevation, slope, soil texture, sand, and the speed of winter and summer wind. The nature of the soil surface in the form of boulders, stones, cobbles and surface gravel is one of the most important factors controlling moisture availability and subsequently the distribution of plant communities in the mountains (Dianati Tilaki et al. 2011). 
We investigated the effect of some soil factors on plant density in one of typical and important rangelands of Iran. We hypothesized that soil can be more efficient on rangelands ecosystems. The selected area is protected so we could waiver other probable effective factors.

\section{MATERIAL AND METHODS}

\section{Study site}

The study site was 482 hectares of typical rangelands of western Iran in Zagros Mountains with elevation from $1854 \mathrm{~m}$ to $2460 \mathrm{~m}$, between $48^{\circ} 23^{\prime} 45.3^{\prime \prime}-48^{\circ} 26^{\prime} 26^{\prime \prime}$ of geographical length and $33^{\circ} 46^{\prime} 37.2^{\prime \prime}-33^{\circ} 47^{\prime} 41.4^{\prime \prime}$ of geographical width (figure 1). The mean annual temperature was $14.6^{\circ} \mathrm{C}$. Annual precipitation has averaged $458.8 \mathrm{~mm}$ since measurements from 1989 until 2009 and daily average is $91.6 \mathrm{~mm}$. More than half of the rain falls in between November until March. The dominant soils could be classified in 3 types: clay, silt-clay and lomy-clay. The average of $\mathrm{pH}$ is 7.8 and $\mathrm{EC}$ is $1 \mathrm{mmhos} / \mathrm{cm}$ so its soil is non-salin type. All herbaceous species present were cool season plants that utilize the $C_{3}$ photosynthetic pathway. Its climate is semiarid and cold (Emberger 1930). A GIS layer mapping in Arc View (3.2) from digitized maps and aerial photographs taken in 2005 was created.

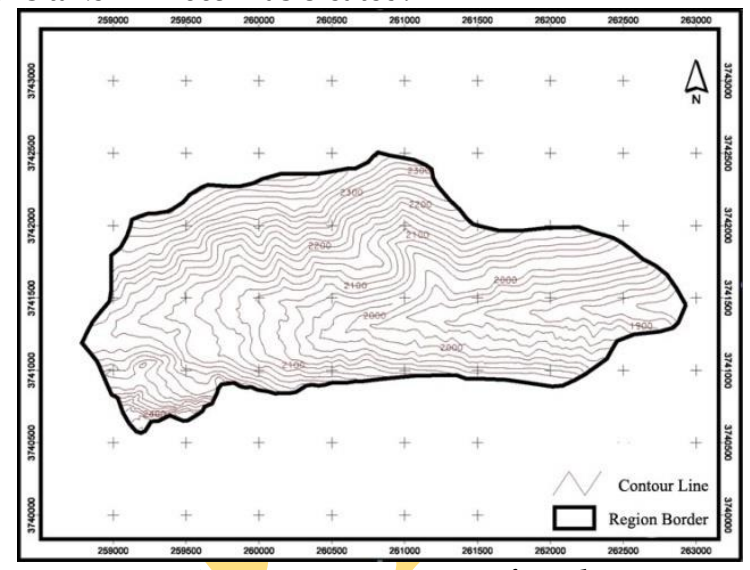

Figure 1 Hypsometric map of study site

\section{Vegetation measurements}

At first all of plant species in the area were specified and key area of each plant type were defined. Plant parameter measured was density. 16, 100-m transects, spaced random in each experimental unit. Density of species was determined by counting all rooted plants in $1 \mathrm{~m}^{2}$ plots. Numbers of plots were 160 based on the minimum level method.

\section{Soil study}

32 soil samples at two depths of 0-30 and $\geq 30 \mathrm{~cm}$ (based on root depth of plant species) were collected from the beginning and the end of each transect. These samples were packed and labeled separately and were transported to laboratory. Then air-dried samples passed through a $2 \mathrm{~mm}$ sieve to remove stone, gravel, shavings and debris, and they were analyzed for texture by Bouyoucos hydrometric method (Bouyoucos 1962), soil organic material percent by Walkey and Black method (Walkley and Black 1934), total nitrogen percent by Kjeldahl method (Kjeldahl 1883), absorbable phosphorus by Olsen method (Olsen and Watanabe 1970) and with spectrophotometer, absorbable potassium by flame photometer, $\mathrm{pH}$ by $\mathrm{pH}$ meter, EC by electrical electric conductivity meter, and lime percent by calcimeter. 


\section{Data analysis}

Classification was conducted with Two-Way Indicator Species Analysis (TWINSPAN) on a data matrix comprising 160 samples. All the default settings were used for TWINSPAN of the computer program PC-ORD for Windows version 4.17 (Mccune and Mefford 1999). Indicator species refer to the preferential species used by TWINSPAN to distinguish the sample groups. The stands are ordered first by divisive hierarchical clustering, and then the species are clustered based on the classification of stands. The TWINSPAN groups were subjected to ANOVA based on soil variables to find out whether there are significant variations among groups.

All data were analyzed by SPSS 17. Comparison of means of squares was performed by Duncan's multiple range tests. To test for the possibility that a significant effect of soil on plant density, we performed ANOVAs (analysis of variance). Significance of differences was tested by using a parametric F-statistics in ANOVA.

\section{RESULTS AND DISCUSSION}

\section{a. Vegetation measurements}

Based on the importance values of 8 species recorded in the 160 studied samples, TWINSPAN technique helped to distinguish four vegetation groups which each group have been named based on dominant species. A dendrogram is depicted in figure 2 . The more eigenvalue the more separability, so overlapping between species was less.

Four plant types were determined and separated in study area as follows:

(1)Agropyron libanoticum H.- Acantholimon bromifolium B.:Distribution of this type was 20 hectare in north part of area. Soil texture of this type was clay. (2)Hordeum glaucum S. Taeniatherum crinitum S.: This type area was 184 hectare in north part. Soil texture of this type was silt clay. (3)Astragalus adscendens B.\& H. - Agropyron trichophorum L.: This type area was 138 hectare in south part. Soil texture of this type was clay. (4)Astragalus adscendens - Daphne mucronata R.: Distribution of this type was 140 hectare. Soil texture of this type was clay.

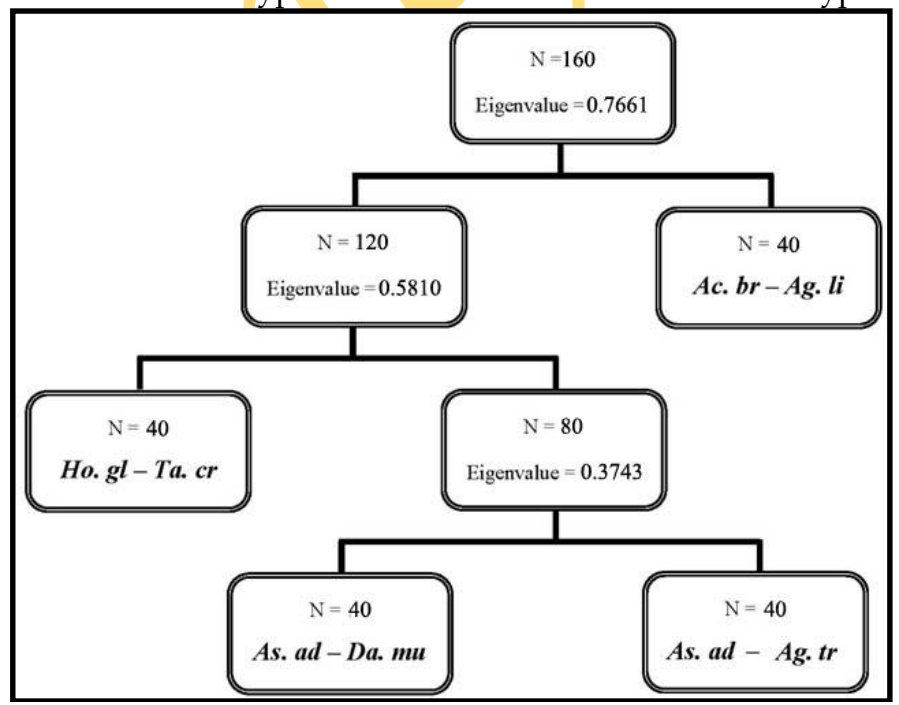

Figure 2 TWINSPAN classifications of the 160 samples in study area. For indicator species abbreviations, see Table 1 


\section{b. Effect of soil factors on species density}

Because of mountainous condition and type of soil in the area, perennial plants have existed more than other types, these species were specific to semiarid areas. Density of them was affected by fertility elements (organic matter, nitrogen and potassium) and clay amount of soil, increasing of these factors caused increased studied plant density. Correlation between soil properties and density coefficients were assessed. Results of soil properties investigation between studied vegetation types, by one-way ANOVA showed that there are significant differences between soil properties of different types. Organic matter, phosphorus, potassium, EC, clay and sand percent, and lime in two depths are significantly different $(\mathrm{P} \leq 0.01)$. Other information is available in Tables 2,3 and 4 . In this experiment $H$. glaucum-T. crinitum were abundant in silt clay soils and other studied plant types establish in clay soils. By Duncan's multiple range tests we can find that each soil factor in each vegetation type was different with another vegetation type. Same letters on columns showed that there is no significant difference between factors (tables 2 and 3). In middle rangelands of Taleghan the results have shown that, 28 plants species of 13 families are found in the study area, and the most density of them is related to Geraminea family. Also, because of mountainous condition, perennial plants with forbs life form were more than the others (Fahimipoor et al. 2010). In a research on seed treatment, between plant abundance there were differences which were due to differential responses of the seeds to heterogeneity. Heterogeneous environments were characterized by more species which reached greater abundances than homogeneous environments. However, there were some species that were abundant in both homogeneous and heterogeneous environments, particularly Eleocharis ovata, Alisma triviale and Sparganium americanum (Vivian-smith 1997). Total production of organic matter or consumption of carbon dioxide has been defined as ecosystem functioning (Hamiltin 2005). Where soil density increases significantly, it limits plant growth by physically restricting root growth. Severe compaction can limit roots to the upper soil layers, effectively cutting off access to the water and nutrients stored deeper in the soil. Near-surface roots, plant litter, and above-ground plant parts reduce the susceptibility to compaction by helping to cushion impacts. Vegetation also adds soil organic matter, which strengthens the soil, making it more resistant to compaction (USDA 2001). Organic matter level as an effective factor on species density was studied. The results showed that effects of organic matter on density of Agropyron trichophorum-Acantholimon bromifolium were more than the others. Clay soil of $A$. adscendens-A. trichophorum and D. mucronata had more nitrogen than $H$. glaucum-T. crinitum soil, density of $A$. adscendens- $A$. trichophorum affected more than other species from soil nitrogen. Salardini(2003) found that proper nitrogen permeation by rainfall is one of effective factors on high soil nitrogen level (Salardini 2003), our results consistent with this finding; the more density of $A$. adscendens- $A$. trichophorum and $A$. adscendens-D. mucronata region, the more maintenance of rainwater in soil, so nitrogen sedimentation will increase.

Another element which affected species density is potassium which its effect on A. bromifolium- $A$. libanoticum were more than other species. Najafitireshabankare (2008) showed that in Geno protected area, potassium had the most effect on separation of plant community (Najafi tireshabankare 2008). Lime influenced vegetation density too; its effect on $A$. trichophorum was more than other species. Moghimi (2005) revealed that habitat of A. trichophorum is calcareous region (Moghimi 2005). Pirisahragarad (2009) indicated that lime is an important property of soil in vegetation dispersion (Pirisahragarad 2009). Jafari et al.(2002) referred to this case (Jafari et al. 2002). According to these findings identification of soil factors is very necessary in determination of index environmental properties of each species, and reclamation and repair of rangelands.

\section{References}

Allen, V. G., C. Batello, E. J. Berretta, et al. 2011. An international terminology for grazing lands and grazing animals. Grass Forage Sci.66:2-28.

Bouyoucos, G. J. 1962. Hydrometer method improved for making particle size analysis of soils. Agron J. 54: 464-465. 
Asia Pacific Journal of Energy and Environment, Volume 1, No 1 (2014)

Dianati Tilaki, Gh. A., H. Naderi Nasrabad, and J. Abdollahi. 2011. Investigation of relationship between vegetation, topography and some soil physic-chemical characteristics in Nodoushan rangelands of Yazd province(Iran). Int. J. Nat. Res. Mar. Sci. 1(2): 147-156.

Emberger, L. 1930. La végétation de la region méditer- ranéenne. Essai d'une classification des grou- pements végétaux. Revue générale de botanique 42: 641-662, 705-721.

Fahimipoor, E., M. A. Zare Chahouki, M. Jafari, M. Goldansaz, Z. Mohhebi. 2010. Investigation of Plant Diversity in Middle Rangelands of Taleghan by Using BIO-DAP. J. Range. Sci. 1(1): 47-51.

Grace, J. B. 1999. The factors controlling species density in herbaceous plant communities: an assessment. Perspect. Plant Ecol. 2(1): 1-28.

Hamiltin, A. J. 2005. Species diversity or biodiversity?. J. Environ. Manage.74:89-92.

Jafari, M., H. Azarnivand, A. Madahi, and H. Arzani. 2002. Effective factors on plant types in Palaya(Semnan) rangelands borders. Desert 7(1): 111-121.

Kjeldahl, J. Z. 1883. A new method for the determination of nitrogen in organic bodies. Anal. Chem. 22: 366.

Mccune, B.,Mefford, M. J. 1999: PC-ORD for windows. Multivariate analysis of ecological data. User's guide. MjM Software, Oregon, USA.

Mirzaiee, J., M. AkbariNia, S. M. Hosseini, H. Sohrabi, and J. Hosseinzadeh. 2007. Species diversity of herbaceous plants relationships with physiographic factors in forest ecosystems of middle Zagros. Iran. J. Boil. 20(4): 375-382.

Moghimi, J. 2005. Introduction of some important range species which are proper to development and modification of Iran rangelands. Arvan press. Tehran. Iran.

Najafi tireshabankare, K. 2008. Study of ecological factors and plant communication distribution in Geno protected area. Iran. J. Range Desert Res.15(2): 179-199.

Olsen, S. R. and F. S. Watanabe. 1970. Diffusive supply of phosphorus in relation to soil texture variations. Soil Sci. 110: 318-327.

Pirisahragarad, H. 2009. Effective environmental factors on plant communication distribution in Taleghan watershed. MsC. Diss., Department of natural resources, University of Tehran. Iran.

Salardini A (2003) Soil fertility. University of Tehran press. Tehran. Iran.

USDA, Natural Resources Conservation Service. 2001. Rangeland Soil Quality:Compaction. Soil Quality Information Sheet, Rangeland Sheet 4.

Vivian-smith, G. 1997. Microtopographic heterogeneity and floristic diversity in experimental wetland communities. J. Ecol. 85: 71-82.

Walkley, A. and I. A. Black. 1934. An examination of the Degtjareff method for determining organic carbon in soils: Effect of variations in digestion conditions and of inorganic soil constituents. Soil Sci. 63: 251-263.

Table1 Species abbreviation of 4 ecological groups

\begin{tabular}{cc}
\hline species & Species abbreviation \\
\hline Acantholimon bromifolium & Ac. br. \\
\hline Agropyron libanoticum & Ag. li. \\
\hline Hordeum glaucum & Ho. gl. \\
\hline Taeniatherum crinitum & Ta. cr. \\
\hline Astragalus adscendens & As. ad. \\
\hline Daphne mucronata & Da mu. \\
\hline Agropyron trichophorum & Ag. tr.
\end{tabular}


Asia Pacific Journal of Energy and Environment, Volume 1, No 1 (2014)

Table 2 Soil factors variation in vegetation types at first depth

\begin{tabular}{cccccccccc}
\hline $\begin{array}{c}\text { Plant } \\
\text { type }\end{array}$ & $\mathrm{N}$ & $\mathrm{P}$ & $\mathrm{K}$ & $\mathrm{pH}$ & $\mathrm{EC}$ & Clay & Silt & Sand & Lime \\
\hline $\begin{array}{c}\text { A. libanoticum } \\
\text { A. bromifolium }\end{array}$ & $0.18 \mathrm{BC}$ & $24.02 \mathrm{~A}$ & $596.3 \mathrm{~A}$ & $7.88 \mathrm{~A}$ & $1.08 \mathrm{~B}$ & $50.87 \mathrm{~A}$ & $36.5 \mathrm{~B}$ & $12.62 \mathrm{~B}$ & $4.6 \mathrm{D}$ \\
\hline $\begin{array}{c}\text { H. glaucum } \\
\text { T. crinitum }\end{array}$ & $0.16 \mathrm{C}$ & $13.6 \mathrm{~B}$ & $412.62 \mathrm{C}$ & $7.78 \mathrm{~A}$ & $1.15 \mathrm{AB}$ & $44.87 \mathrm{~B}$ & $40.62 \mathrm{~A}$ & $14.5 \mathrm{~B}$ & $8.9 \mathrm{~B}$ \\
\hline $\begin{array}{c}\text { A. adscendens } \\
\text { A. trichophorum }\end{array}$ & $0.25 \mathrm{~A}$ & $22.17 \mathrm{~A}$ & $442.25 \mathrm{~B}$ & $7.81 \mathrm{~A}$ & $1.2 \mathrm{~A}$ & $47.12 \mathrm{~B}$ & $40 \mathrm{~A}$ & $12.87 \mathrm{~B}$ & $12.3 \mathrm{~A}$ \\
\hline $\begin{array}{c}\text { A. adscendens } \\
\text { D. mucronata }\end{array}$ & $0.21 \mathrm{~B}$ & $14.95 \mathrm{~B}$ & $430.12 \mathrm{BC}$ & $7.75 \mathrm{~A}$ & $1.91 \mathrm{C}$ & $39.75 \mathrm{C}$ & $40.87 \mathrm{~A}$ & $19.37 \mathrm{~A}$ & $6.9 \mathrm{C}$ \\
\hline
\end{tabular}

In each column same letters show that there are no significantly difference according to Duncan's multiple ranges

Table 3 Soil factors variation in vegetation types at second depth

\begin{tabular}{cccccccccc}
\hline $\begin{array}{c}\text { Plant } \\
\text { type }\end{array}$ & $\mathrm{N}$ & $\mathrm{P}$ & $\mathrm{K}$ & $\mathrm{pH}$ & $\mathrm{EC}$ & $\mathrm{Clay}$ & $\mathrm{Silt}$ & Sand & Lime \\
\hline $\begin{array}{c}\text { A. libanoticum } \\
\text { A. bromifolium }\end{array}$ & $0.13 \mathrm{~A}$ & $11.65 \mathrm{~A}$ & $391.12 \mathrm{~A}$ & $7.73 \mathrm{AB}$ & $1.16 \mathrm{~A}$ & $58.12 \mathrm{~B}$ & $30 \mathrm{C}$ & $11.87 \mathrm{~B}$ & $4.6 \mathrm{D}$ \\
\hline $\begin{array}{c}\text { H. glaucum } \\
\text { T. crinitum }\end{array}$ & $0.07 \mathrm{~A}$ & $2.72 \mathrm{~B}$ & $210 \mathrm{~B}$ & $7.68 \mathrm{~B}$ & $0.74 \mathrm{C}$ & $64.75 \mathrm{~A}$ & $23 \mathrm{D}$ & $12.25 \mathrm{~B}$ & $6.71 \mathrm{C}$ \\
\hline $\begin{array}{c}\text { A. adscendens } \\
\text { A. trichophorum }\end{array}$ & $0.09 \mathrm{~A}$ & $3.97 \mathrm{~B}$ & $175.12 \mathrm{C}$ & $7.83 \mathrm{~A}$ & $0.99 \mathrm{~B}$ & $50.87 \mathrm{C}$ & $36.25 \mathrm{~B}$ & $12.87 \mathrm{~B}$ & $11.96 \mathrm{~A}$ \\
\hline $\begin{array}{c}\text { A. adscendens } \\
\text { D. mucronata }\end{array}$ & $0.18 \mathrm{~A}$ & $3.87 \mathrm{~B}$ & $202.37 \mathrm{BC}$ & $7.75 \mathrm{AB}$ & $0.75 \mathrm{C}$ & $42.25 \mathrm{D}$ & $39.87 \mathrm{~A}$ & $17.87 \mathrm{~A}$ & $9.18 \mathrm{~B}$ \\
\hline
\end{tabular}

In each column same letters show that there are no significantly difference according to Duncan's multiple ranges

Table 4 One-Way ANOVA: soil factor effects

\begin{tabular}{|c|c|c|c|c|c|}
\hline \multirow[b]{2}{*}{ factor } & \multicolumn{4}{|c|}{ MS } & \multirow[b]{2}{*}{ F } \\
\hline & $\begin{array}{l}\text { Depth } \\
\text { (cm) }\end{array}$ & $\begin{array}{c}\text { Between groups } \\
(\mathrm{DF}=-3)\end{array}$ & $\begin{array}{l}\text { Within groups } \\
(\mathrm{DF}=-28)\end{array}$ & $\begin{array}{c}\text { Total } \\
(\mathrm{DF}=-31)\end{array}$ & \\
\hline \multirow[b]{2}{*}{ Organic matter } & $0-30$ & 9.734 & 6.422 & 16.156 & $14.147^{* *}$ \\
\hline & $>30$ & 4.42 & 2.601 & 7.021 & $15.863^{* *}$ \\
\hline \multirow{2}{*}{ Total nitrogen } & $0-30$ & 0.035 & 0.023 & 0.058 & $14.158^{* 4}$ \\
\hline & $>30$ & 0.049 & 0.448 & 0.496 & $1.012^{*}$ \\
\hline \multirow{2}{*}{ Phosphorus } & $0-30$ & 643.822 & 154.93 & 798.752 & $38.785^{44}$ \\
\hline & $>30$ & 403.701 & 317.257 & 720.958 & $11.876^{4 *}$ \\
\hline \multirow[b]{2}{*}{ Potassium } & $0-30$ & 172977.094 & 18758.125 & 191735.219 & $86.067^{* *}$ \\
\hline & $>30$ & 234211.594 & 28679.625 & 262891.219 & $76.22^{* *}$ \\
\hline \multirow[b]{2}{*}{ pH } & $0-30$ & 0.081 & 0.566 & 0.647 & $1.334^{*}$ \\
\hline & $>30$ & 0.093 & 0.306 & 0.4 & $2.848^{*}$ \\
\hline \multirow[b]{2}{*}{ EC } & $0-30$ & 0.375 & 0.215 & 0.59 & $16.303^{* 4}$ \\
\hline & $>30$ & 0.987 & 0.275 & 1.262 & $33.521^{* 4}$ \\
\hline \multirow{2}{*}{ Clay percent } & $0-30$ & 519.094 & 346.125 & 865.219 & $13.997^{* *}$ \\
\hline & $>30$ & 2243.25 & 356.75 & 2600 & $58.688^{* *}$ \\
\hline \multirow[b]{2}{*}{ Silt percent } & $0-30$ & 99.25 & 182.75 & 282 & $5.069^{*}$ \\
\hline & $>30$ & 1318.094 & 220.375 & 1538.469 & $55.824^{* *}$ \\
\hline \multirow{2}{*}{ Sand percent } & $0-30$ & 235.594 & 96.625 & 332.219 & $22.757^{4 *}$ \\
\hline & $>30$ & 188.344 & 80.125 & 268.469 & $21.939^{* *}$ \\
\hline \multirow{2}{*}{ Lime } & $0-30$ & 254.823 & 81.559 & 336.382 & $29.161^{* *}$ \\
\hline & $>30$ & 242.206 & 44.916 & 287.122 & $50.329^{* *}$ \\
\hline
\end{tabular}

**: significantly difference $(\mathrm{P} \leq 0.01)$

*: significantly difference $(\mathrm{P} \leq 0.05)$ 